\title{
REGIONAL DISPARITIES OF AGRICULTURAL PERFORMANCE IN ROMANIA
}

\author{
Vasile Burjal
}

\begin{abstract}
The accession to the European Union has opened new challenges for Romanian agriculture, which must implement the principles of the Common Agricultural Policy. These principles aim at achieving high performance agriculture, capable to ensure food security for the population and to adequately develop the rural area. The paper intends to analyse the performance of Romanian agriculture in relation to the agriculture in the European Union and to highlight the recorded regional disparities in order to fully exploit the potential of agriculture. Data Envelopment Analysis is the used method, which provides information for the relative assessment of performance in relation to the decision-making units, considered a gauge. The results of the analysis show the poor performance of agriculture in Romania, and the efficiency recorded at the level of the development regions varies.
\end{abstract}

Key words: agriculture, Data Envelopment Analysis, sustainable performance, efficiency frontier, developing regions

JEL codes: N50, O13, Q001

\section{Introduction}

Agriculture has played a major role in the development of society since ancient times. The new paradigm of sustainable development emphasizes the role of agriculture in accelerating economic growth, providing food security, reducing poverty, narrowing income disparities, developing the rural area and protecting the environment (Byerlee et al., 2009).

Achieving the functions of agriculture involves developing it on principles of economic, social and environmental performance, which means efficiently using the available and attracted resources. In economy, performance implies achieving the desired efficiency in relation to a certain system; therefore it isn't reduced to a mere comparison between effect and effort.

Romanian agriculture has great potential, which is not properly exploited. The Eurostat data show that Romania is ranked seventh in Europe in terms of agricultural area and fifth in terms of arable land. The arable land per habitant is 0.42 ha of land, a value higher than most European countries and almost double than the European average ( 0.236 ha/habitant). In 2008, Romania ranked fourth within the EU in terms of cereal crops (5.2 million ha), behind France ( 9.6 million ha), Poland ( 8.9 million ha) and Germany ( 7 million ha). The average cereal yield in Romania (3400 kg/ha) is almost half of the EU average (5960 kg/ha, EU-25).

Even though Romania has a varied landscape, all the regions of the country have favourable conditions for agriculture. The analysis of the results recorded by Romanian agriculture on regions of development shows important disparities. Therefore, it's required to permanently monitor agricultural performance recorded at regional level. Monitoring provides decision makers with the necessary information to take restructuring measures of the technical and productive systems intended to contribute in achieving a productive agriculture throughout the country.

The purpose of this paper is to conduct a diagnosis analysis of the performance of Romanian agriculture, studied through the correlation between obtained results and used production factors, in

\footnotetext{
1 “1 Decembrie 1918” University of Alba Iulia, Faculty of Science, Romania, e-mail: vasileburja@yahoo.com
} 
comparison with the average level recorded by the European Union. The comparison with the EU average takes into account the national objective stipulated by the National Sustainable Development Strategy for 2003: "To come close to the average level attained at that time by the other EU Member States in terms of sustainable production and consumption" (NSDS, 2008).

The comparison method and Data Envelopment Analysis (DEA) are used to achieve the targeted goal. DEA allows assessing territorial performance of agriculture based on an efficiency score, highlighting the competitiveness differences between regions and suggesting the necessary adjustments for inefficient agricultural systems. The information necessary for analysis comes from the data base of the European Union (Eurostat) and Farm Accountancy Data Network (FADN), which is an instrument for evaluating the income of agricultural holdings and the impacts of the Common Agricultural Policy.

The results of the analysis show that Romanian agriculture has poor performances in comparison to the agriculture in the European Union. The existent regional disparities prove that the potential of Romanian agriculture is insufficiently exploited, and an organizational and functional restructuring might increase the performance and competitiveness of agriculture.

\section{Methodology}

In economic practice, Data Envelopment Analysis is used for the valuation of performance and competitiveness of decision-making units (companies, institutions) and proved to be a valuable management tool that underlain the approach and decisions to organizationally restructure various activity branches and sectors at local, regional or national level.

Literature reflects the widespread of DEA in studying performance in agriculture, such as: the evaluation of sustainable agriculture (Ehrmann and Kleinhanss, 2008), explaining agricultural productivity growth (Headey et al., 2010), determinants of technical efficiency of crop and livestock farms (Latruffe et al., 2004), the assignment of new European agricultural subsidies (Amores and Contreras, 2009), technical efficiency and technology in agriculture (Fogarasi and Latruffe 2007).

Economic systems whose performance is assessed by DEA, called also decision making units (DMUs) have similar operational features, but are singularized through the available production factors and the size of the unreeled economic activities.

DEA is an alternative method to the regression analysis, which establishes an optimal allocation of resources or achieves results, by making a comparison with one or several reference systems identified as having maximum efficiency. Efficient units are part of a production frontier that envelops inefficient units.

The DEA approach doesn't need to know the functional relationship that correlates consumed resources with outputs, being considered a non-parametrical measuring method of the efficiency of DMUs. Another advantage of using DEA against regression is the low volume of information needed to study multiple inputs and outputs. At the same time, the flexibility feature of the method allows using a wide range of indicators to express input variables or outputs, which increases the applicability range of the method (Thanassoulis, 2009). DEA models provide for each organization a measurement of overall performance, which ensures the possibility of ranked alternative valuations that may be useful for some decision makers (Sarkis, 2000).

Initially, DEA was used as a model that has constant returns to scale (CRS), called also CCR after its creators Charnes, Cooper and Rhodes (1978). Subsequently, other models were developed by Banker, Charnes and Copper (1984), which are applicable to technologies with variable returns to scale (VRS). For a better understanding of the mathematical content of DEA, Cooper, Seifort and Tone(2006) have recently developed various analysis models and Ray (2004) approached the main technical aspects in a manner correlated with DEA's economic fundamentals.

DEA must pay special attention to choosing the analysis model, inputs or outputs, upon which the obtained results depend, as does the credibility level of the conducted valuation (Berg 2010). It is also recommended to have a higher number of analyzed units that the sum of inputs and 
outputs. Therefore, at the beginning is necessary to limit the number of variables taken into account and by gradually increasing them we will notice their effect on performance (Cooper et al., 2006).

Being widely used in the analysis of technical efficiency, the CCR model considers $k$ decision making units that have $n$ inputs and $m$ outputs.

The efficiency of decision making unit $k$ is:

$$
E_{k}=\frac{\sum_{j=1}^{m} v_{j} y_{k j}}{\sum_{i=1}^{n} u_{i} x_{k i}}
$$

subject to:

$$
\frac{\sum_{j=1}^{m} v_{j} y_{k j}}{\sum_{i=1}^{n} u_{i} x_{k i}} \leq 1
$$

$$
\forall u_{i}, v_{i} \geq 0
$$

where: $u_{i}$ represents inputs weight $(x)$;

$v_{j}$ represents outputs weight $(y)$.

This system of relations can be transformed into a linear programming model that includes a set of restrictions and the minimization objective (inputs orientated models) or the maximization objective (output orientated models), where unknown elements are the given weight to inputs and outputs. For each decision making unit $k$, the following model is developed:

$$
\begin{array}{cl}
\max & \sum_{j=1}^{m} v_{j} y_{k j} \\
\text { s.t. } \quad \sum_{i=1}^{n} u_{i} x_{k i}=1 \\
\sum_{j=1}^{m} v_{j} y_{k j}-\sum_{i=1}^{n} u_{i} x_{k i} \leq 0 \\
\forall u_{i}, v_{j} \geq 0
\end{array}
$$

Solving the model leads to finding out the weight of the input and output variables and of a single score of general efficiency (for all inputs and outputs). We will identify one or several efficient DMUs (score 1) that create an efficiency frontier for production and play the role of reference systems for the other units with a low score. For inefficient decision making units, weights represent the target adjustment values of inputs and outputs, which, if achieved, will ensure their positioning on the production frontier where efficient DMUs are placed (Andree et al, 2010).

\section{Results and discussion}

Romanian agriculture is characterized by a large number of small-sized agricultural holdings with an excessively fragmented agricultural area. In addition, it's characterized by poor endowment 
with machines and equipment, precarious state of rural infrastructure, low amounts of chemical or organic fertilizers and pesticides used, dramatic reduction of irrigated areas, soil degradation, chronic deficit of available financing and the absence of a functional system of farming credit (SNDDR, 2008).

The mentioned features give Romanian agriculture a feature of subsistence. The data in table no. 1 provide a picture of the Romanian agriculture's characteristics compared to the situation in the European Union.

Table no.1

Aspects of agriculture in Romania and the EU - year 2008

\begin{tabular}{|l|c|r|r|c|}
\hline \multicolumn{1}{|c|}{ Indicators } & M.U. & Romania & EU & $\begin{array}{c}\text { Romania/EU } \\
\text { \% }\end{array}$ \\
\hline Agricultural output (AO) & Mill. euro & 4261,97 & 151453,53 & 2,8 \\
\hline Net value added (NVA) & Mill. euro & 6352,12 & 97211,11 & 6,5 \\
\hline Energy, lubricants (EL) & Mill. euro & 1392,44 & 26727,87 & 5,2 \\
\hline Fixed capital consumption (FCC) & Mill. euro & 2009,68 & 54491,70 & 3,7 \\
\hline Fertilisers and soil improvers (FSI) & Mill. euro & 673,16 & 18851,33 & 3,6 \\
\hline $\begin{array}{l}\text { Plant protection products, } \\
\text { herbicides, insecticides and } \\
\text { pesticides (PHIP) }\end{array}$ & Mill. euro & 245,85 & 10429,68 & \\
\hline Agricultural Labour Input (ALI) & 1000 AWU & 2152,0 & 11251,1 & 19,1 \\
\hline Utilised agricultural area (UAA) & 1000 ha & 13717 & 178741 & 7,7 \\
\hline Number of Farms* & Nr. & 3931350 & 13700400 & 28,7 \\
\hline AO/UAA & Euro/ha & 310,7 & 847,3 & 36,7 \\
\hline AO/ALI & Euro/AWU & 1980,5 & 13461,2 & 14,7 \\
\hline
\end{tabular}

Source: Eurostat

* year 2007

Table 1 shows that Romania holds $7.7 \%$ of the utilised agricultural area in the European Union, but achieves only $2.8 \%$ of the agricultural output. The yield of Romanian agriculture (AO/UAA) is approximately 2.7 times lower that of the European Union (36.7\%), and labour productivity (AO/ALI) is approximately 6.8 times lower (18.5\%). These aspects are caused by the existence of a large number of small-sized agricultural holdings in Romania (average size of agricultural holdings is 3.5 ha/holding in Romania, and 13 ha/holding in the EU) and by the technical factors used in agriculture (mechanisation, chemical processing and energy consumption), which are superior in the European Union.

Romanian agriculture has different results in terms of territorial performance. We will use data from FADN to analyze agricultural performance on regions of development in Romania compared to the situation in the EU. This database includes a wide series of economic, financial and social indicators regarding the situation of "average farms", calculated on the basis of a representative sample. The data in FADN summarize the characteristics of agriculture in each region, achieving harmonization and homogenization of the indicators used in analysis of agricultural performance. Table no. 2 presents an overview of the issues characterizing on regions the situation of agricultural holdings in Romania, compared to the European Union. The BucharestIlfov region is atypical, having low weight in Romanian agriculture, and therefore was excluded. 
Indicators caracteristic for agricultural holdings, on regions, year 2008

\begin{tabular}{|l|r|r|r|r|c|}
\hline \multicolumn{1}{|c|}{ Regions } & $\begin{array}{c}\text { Agricultural } \\
\text { output, } \\
\text { euro }\end{array}$ & $\begin{array}{c}\text { Utilized } \\
\text { Agricultural } \\
\text { area,ha }\end{array}$ & $\begin{array}{c}\text { Labour } \\
\text { input, AWU }\end{array}$ & $\begin{array}{c}\text { Machinery, } \\
\text { Euro }\end{array}$ & $\begin{array}{c}\text { Fertilisers + } \\
\text { Crop protection } \\
\text { Euro }\end{array}$ \\
\hline North-East & 9446 & 7.68 & 1.39 & 4912 & 712 \\
\hline South-East & 15270 & 17.67 & 1.26 & 5814 & 1305 \\
\hline South-Muntenia & 13589 & 13.5 & 1.23 & 4774 & 1289 \\
\hline South-West Oltenia & 10378 & 10.7 & 1.4 & 4002 & 1025 \\
\hline West & 13706 & 17.32 & 1.53 & 14888 & 1268 \\
\hline North-West & 12310 & 9.53 & 1.56 & 6465 & 994 \\
\hline Center & 18447 & 13.5 & 1.34 & 11795 & 1166 \\
\hline Total (Region) Romania & 18842 & 12.52 & 1.39 & 6949 & 1124 \\
\hline Total (Region) EU & 64834 & 34.61 & 1.66 & 30048 & 6282 \\
\hline
\end{tabular}

Source: FADN

Table no. 2 shows significant differences between agricultural holdings in Romania and the EU. The agricultural output is almost 3.5 times higher in agricultural holdings in the EU than in Romania. This is explained by the utilised agricultural area, which is less by 2.7 times in Romania. In addition to this, there is technical endowment with agricultural machinery, the fertilisers' value and crop protection, which are 4.3 times and 5.6 times higher.

At the same time, agricultural holdings have different features depending of the development region in Romania. In the Center region, agricultural output is almost two times higher than in the North-East region due to better technical endowments, fertilisers and crop protection.

A synthetic picture of agricultural holdings' performances on development regions can be achieved by using DEA. Because in DEA the number of inputs and outputs is restricted by the number of Decision Making Units (DMUs), we'll analyze regional performance by taking into account one output (agricultural output) and three inputs (utilized agricultural area, machinery and labour input). Fertilisers and crop protection are strongly correlated with machinery and may be excluded from the analysis. Table 3 presents the assessment of agricultural performance in development regions in Romania and the EU, using DEA, output orientated and scale assumption VRS.

Table no.3

Performance of regional agriculture DEA

\begin{tabular}{|l|c|c|c|c|}
\hline \multicolumn{1}{|c|}{ Regions } & crste & vrste & scale & $\begin{array}{c}\text { Returns } \\
\text { to-Scale }\end{array}$ \\
\hline North-East & 0.826 & 1.000 & 0.826 & irs \\
\hline South-East & 0.970 & 0.973 & 0.997 & drs \\
\hline South-Muntenia & 1.000 & 1.000 & 1.000 & - \\
\hline South-West Oltenia & 0.932 & 1.000 & 0.932 & irs \\
\hline West & 0.426 & 0.468 & 0.909 & irs \\
\hline North-West & 0.831 & 0.946 & 0.879 & irs \\
\hline Center & 0.729 & 1.000 & 0.729 & irs \\
\hline EU & 1.000 & 1.000 & 1.000 & - \\
\hline Mean & 0.839 & 0.923 & 0.909 & - \\
\hline \multicolumn{4}{|l|}{ Source: computations were performed using Deap 2.1 }
\end{tabular}

Note: crste $=$ technical efficiency from CRS DEA vrste $=$ technical efficiency from VRS DEA scale $=$ scale efficiency $=$ crste $/$ vrste 
Table no. 3 shows that in the case of CRS assumption, only agricultural holdings in the South-Muntenia region are positioned on the efficiency frontier next to those in the EU. A performance above average is recorded by South-East and South-West Oltenia regions. The lowest performance is recorded by West region (0.426). This aspect is due to the low yield of production factors used by agricultural holdings in this region. Table no. 2 shows that agricultural holdings in the West region achieve an agricultural output approximately equal to the output in the SouthMuntenia region, but technical endowment is over three times higher.

Three more regions are positioned on the efficiency frontier in terms of an assumption of variable returns to scale (VRS): North-East, South-West Oltenia and Center. This aspect highlights that there are opportunities to improve the economic performance of agriculture in Romania by reconfiguring the used production factors and increasing their yield. In all the regions (except the South-East region) that were not located on the efficiency frontier under CRS assumption, the production factors' yield is increasing returns to scale (irs).

\section{Conclusions}

Sustainable performance of agriculture involves using efficiency principles of technical, economic, social and environmental production factors. This way, agriculture becomes a stability factor of national economy and contributes to the sustainable development of the rural area. In the paper, performance is valuated in relation to the regions considered a gauge in terms of efficiency, meaning the ration between effect (output) and efforts (input). We don't aim to achieve an "absolute" maximum efficiency, but only a "relative" maximum efficiency, this being one of the limitations of the DEA method.

Romania is a country recently integrated into the European Union, having a significant agricultural potential. This potential isn't sufficiently exploited because of excessive land fragmentation, aging of the population active in agriculture, using inadequate technologies, insufficient financing sources and poor agricultural management (Burja and Burja, 2010). As a result, Romanian agriculture is largely subsistence agriculture, with low productivity, uncompetitive on the EU market and with a deficit in food trade. Comparisons made by using the EUROSTAT data have highlighted the poor performance of Romanian agriculture in relation to the EU, materialized in the obtained yield and labour productivity.

The performance of agriculture in Romania is uneven on development regions. The analysis conducted in the paper allowed to emphasize the existent disparities and to assess sustainable performance in agriculture in relation to regions considered a standard.

Using DEA allowed identifying a synthetic efficiency score, taking into account an agricultural output and three agricultural inputs (utilized agricultural area, machinery and labour input). In terms of CRS, only the South-Muntenia region falls on the efficiency frontier where agricultural holdings in the EU are positioned. The West region recorded the lowest agricultural performance due to inadequate yields of production factors, particularly technical capital. In most regions, the yield of production factors is increasing returns to scale, which proves there are opportunities to improve agricultural performance in the other regions by making new combinations between production factors and increasing their yield. This way, an efficient agriculture in compliance with sustainable development principles and performance parameters specific to the EU is achieved.

\section{References}

1. Andre F., Herrero I., Riesgo L., 2010. Using a Modified DEA Model to Estimate the Importance of Objectives. An Application to Agricultural Economics, Omega, 38(5), pp.371-382. 
2. Amores A. F., Contreras I., 2009. New approach for the assignment of new European agricultural subsidies using scores from data envelopment analysis: application to olivegrowing farms in Andalusia (Spain). European Journal of Operational Research vol. 193(3), pp.718-729.

3. Banker R.D., Charnes A., Cooper W.W., 1984. Some Models for Estimating Technical and Scale Inefficiencies in Data Envelopment Analysis, Management science, vol. 30, no. 9, pp.1078-1092.

4. Berg S., 2010. Water Utility Benchmarking: Measurement, Methodology, and Performance Incentives. International Water Association.

5. Burja C., Burja V., 2010. Sustainable value analysis for Romanian agriculture, Environmental Engineering and Management Journal June 2010, Vol.9, No.6, pp. 839-846.

6. Byerlee D., de Janvry A., Sadoulet E., 2009. Agriculture for Development: Toward a New Paradigm, Annual Review of Resource Economics, Vol. 1, pp. 15 -31.

7. Charles A., Cooper W.W., Rhodes E., 1978. Measuring the efficiency of decision making units, European Journal of Operational Research, vol.2, pp. 429-444.

8. Cooper W.W., Seiford L.M., Tone K., 2006. Data envelopment analysis - a comprehensive text with models applications references and DEA-solver software. 2nd ed. New York, Springer.

9. Ehrmann M., Kleinhanss W., 2008. Review of concepts for the evaluation of sustainable agriculture in Germany and comparison of measurement schemes for farm sustainability, Arbeitsberichte aus der vTI-Agrarökonomie, no.14/2008, Johann Heinrich von ThünenInstitut - Federal Research Institute for Rural Areas, Forestry and Fisheries.

10. Eurostat database, available at http://epp.eurostat.ec.europa.eu.

11. Fogarasi J., Latruffe L., 2007. Technical efficiency and technology in Eastern and Western agriculture: A comparison of crop and dairy farms in Hungary and France, European Association of Agricultural Economists, 104th Seminar, September 5-8, 2007, Budapest, Hungary.

12. Headey D., Alauddin M., Rao D.S,P., 2010. Explaining agricultural productivity growth: an international perspective, Agricultural Economics, Vol. 41, Issue 1, pp. 1-14.

13. Latruffe L., Balcombe K., Davidova S., Zawalinska K., 2004. Determinants of technical efficiency of crop and livestock farms in Poland, Applied Economics, Taylor and Francis Journals, vol. 36(12), pp. 1255-1263.

14. Ministry of Environment and Sustainable Development, 2008. National strategy for sustainable development, Romania 2013-2020-2030 Bucharest, Romania, available at http://www.mmediu.ro/vechi/dezvoltare_durabila/sndd.htm

15. Ray S.C., 2004. Data Envelopment Analysis: Theory and Techniques for Economics and Operations Research, Cambridge University Press, UK.

16. Sarkis J., 2000. A Comparative Analysis of DEA as a Discrete Alternative Multiple Criteria Decision Tool. European journal of operational research, 123(3) pp. 543-557.

17. Thanassoulis E., Kortelainen M., Johnes G., Johnes J., 2009. Costs and efficiency of Higher Education Institutions in England: a DEA Analysis, LUMS Working Paper 2009/008, available at http://www.lums.lancs.ac.uk/publications/viewpdf/005896/. 